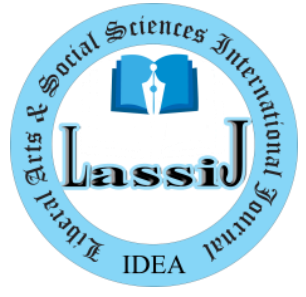

ISSN: 2664-8148 (Online)

Liberal Arts and Social Sciences

International Journal (LASSIJ)

https: / / doi.org/10.47264/idea.lassij/1.2.3

Vol. 1, No. 2, (July-December) 2017, 24-33

https://www.ideapublishers.org/lassij

\title{
Government-Opposition Relations during Benazir Bhutto's Rule in Pakistan
}

\author{
Ashfaq U. Rehman ${ }^{1-2}$, Arif Khan ${ }^{1 *}$ and Bakhtiar Khan ${ }^{1}$
}

1. Department of Political Science, University of Peshawar, Peshawar Pakistan.

2. Department of Research and Program Development, IDEA Peshawar, Pakistan.

\begin{abstract}
Democracy, transition to democracy and democratic consolidation have widely been debated across the world and have prominent position in third world countries. Democracy in developing countries particularly in Pakistan is confronting long standing problem of consolidation of power by civilians. In democracy the strength of the state institutions depends on the relationship among central government with opposition and with provincial governments. Pakistan consists of a centre and four federating units having mix nationalities. This paper investigates the factors which have provoked confrontational politics both within the parliament between ruling and opposition parties and with provincial governments especially Punjab during Benazir Bhutto's rule. The paper focuses on the question whether it was the same follies which Benazir Bhutto played with during her second term with opposition in the centre and their governments in provinces. To find answers to these questions, secondary data has been used and to supplement newspapers have been consulted for obtaining first-hand information of public officials. The relationship among the ruling party in the centre with opposition and the provincial governments often remained unpleasant and unfriendly. It is argued that personal the national considerations augmented the confrontation and conflicts among national and regional level political parties.
\end{abstract}

Keywords: Transition to Democracy, Political Parties, Ruling Party, Confrontational Politics

\section{Introduction}

Ideological groups are the necessary actors of the majority rule government. Especially if there should arise an occurrence of delegate government composed ideological groups are critical and the administration cannot work without the gatherings. It is the obligation of the ideological groups to settle political procedure in the nation. It is normal in the popularity based set up that if the ruling party starts practicing less than ideal approaches of democratic culture, it loses the real force and authority and the politics of conflicts and resistance takes overs that political organisation. The resistance likewise presents a workable elective program of its own. Provided that this is true, both decisions just as restriction ideological groups add to the soundness of government and union of majority rule government (Ahmad, Bano, \& Rehman, 2017). Tragically, legislative issues of collaboration and coordination was absent during Benazir Bhutto rule as head administrator. Pakistan's popularity-based trick in post Ziaul Haq time stood out of the researchers towards examining the job of PPP. The period under examination hosts particular attributes on the grounds that the gathering based general decisions in November 1988 set the nation back on the way of popular government. Tragically, this could 
not support because of the contention for political ascendency disregarding the necessities of undeveloped law-based structure that the nation had gotten after a long range of military guideline (1977-1988). The proposed examination looks to inspect the job of PPP for the improvement of majority rules system (people's rule).

\section{Literature Review}

Democracy, political parties, and elections are interconnected. Political parties are a key part of a democratic process and without strong political parties no democracy can function in the true sense (Hofmeister \& Karsten, 2011). Democracy requires freedom and the possession of knowledge coupled with opportunities of participation to the citizens at every level of decision making. In Pakistan, the phenomenon of non-tolerance of the democratic values on the part of leaders from government and the opposition has been deep rooted. Since the country's birth, democratic practices have been used as core against politicians' autocratic attitudes, they were not accommodative and simply advanced their self-interests thus, undermining the future of democracy in Pakistan. Political leaders whether in government, in opposition, the president and the civil and military elites, all played mockery with the basic spirit of the 1973 Constitution of Pakistan. The president displayed the lingering legacy in the shape of Eight Amendment whenever he wanted (Chowdhury, 2003). Saeed Shafqat focused on the dynamism in Benazir Bhutto leadership. Being a popular leader; Benazir Bhutto played a significant role in national politics, both in government as well as in opposition. The Party under her leadership, held intra party elections, which was a clear sign of her commitment towards democracy and Peoples rule (Shafqat, 1997).

Unfortunately, the civilian leaders could not honour the commitment they made prior to the restoration of democratic rule and this caused an irreparable damage to the health of nascent democratic culture of the country (Wynbrandt, 2009). Kapoor has also pinpointed the lacuna and political will of the politicians to transform the state into a democratic polity. It is revealed from the continuous infighting among politicians for lucrative positions. This sowed the seeds of selfishness and corruption in Pakistan (Kapoor, 1991). Burki calls it a period of skirmishes among different rival forces in the country. He has pointed out that while coming into high echelon, the politicians indulged in grabbing and accumulating all the powers in themselves. In doing so, they were unaware of the repercussions. Interrupting other's ambit of power repeatedly virtually provided a chance to the rival covert and overt forces. As a result of this nondemocratic approach of Pakistani political elites, an irreparable damage has been caused to the democratic culture which would take a long time to recover (Burki, 2006). It should, however, be noted here that fall of authoritarian or dictatorial regime does not guarantee or mean that there will be democratic society or political institutions in a state. If with the ouster of autocrats or dictator, the state, the political institutions, the civil society and the people in general do not adopt democratic values then the state may still remain under authoritarian tendencies by civilian leaders (Fatton, 1998).

\section{Methods and Material}

In this research, the PPP's coming into power through the elections of 1988 and the later events that had attracted scholarly attentions needs to be explored. Qualitative tools are used to determine various dimensions and depth of the study. Both historical and descriptive methods are used to look into the nature of the study. To collect the relevant information secondary sources are used. Among secondary sources books more relevant and written by different local and foreign scholars related to this study are analysed. Apart from it, books having chapters on 
this period are also used to get more insight and strengthen this work. Furthermore, online journals, magazines and reputable national newspapers are consulted for the data collection of this study. In addition, the internet and other electronic sources are used to get the most reliable data out of it. Newspapers have also been used for obtaining first-hand information of government official and public representatives.

\section{Discussion and Findings}

This section of the article gives a critical assessment of the relations between the Benazir Bhutto's led coalition governments of PPP with opposition parties and its allies at national level i.e., in parliament and the federal government during her first term and second term as prime minister. The later parts of this portion deals with the relations of PPP led federal/central governments with the provincial governments which either completely led by the opposition parties or PPP ruled along with its allies in provinces also.

\subsection{Cooperation vs Confrontation in National Politics during First Term}

After the election of 1988, PPP was hardly able to form coalition government in the centre. However, keeping the required majority in the House, President Ghulam Ishaq Khan called upon Benazir Bhutto for the formation of government, the first woman to govern a Muslim State. A slight numerical superiority in the general elections of October 1988 i.e., 94 seats in the House of 217, enabled Pakistan People Party (PPP) to form coalition government with likeminded parties at the centre and provinces except that of the Punjab. In Punjab, the rival Islami Jamhoori Ittehad (IJI), an alliance of heterogeneous political parties with Pakistan Muslim League as the largest constituent, was able to form government (Mehmood, 2003). The new political administration led by Benazir Bhutto, was extremely divided before assuming office. Punjab, the most populous province had already gone into the hands of IJI under Nawaz Sharif as its Chief Minister. He was an arch political rival of Benazir Bhutto. He is known as an ideological heir of Ziaul Haq. The regional politicians in Sindh and Baluchistan, who sought provincial autonomy, thought that Benazir Bhutto was weak. The circumstances, in which Benazir Bhutto became Prime Minister with a split mandate in the Parliament made her bound to compromise various political goals (Sirohey, 2000). Moreover, the death of President Ziaul Haq in August 1988 had also paved the way for the emergence of a "troika." The agreement, reached under the pressure, confirmed the powers of the military and overall controllers of the politics (Aziz, 2009).

At the outset of her rule Benazir Bhutto opted for the path of pacifying politics towards opponent political parties including IJI led by Nawaz Sharif. She admirably sorted out differences between Muhajir and Sindh leadership. PPP's leadership was also able to convince Awami National Party (ANP) which was an arch-rival of PPP in the mid-1970s, to share government with PPP in Khyber Pakhtunkhwa (then NWFP). However, all these measures did not favour Benazir Bhutto and soon the differences surfaced in the relationship of various stakeholders in the corridors of powers. Personal interests overshadowed national interests which inadvertently deteriorated smooth functioning of democracy in Pakistan. To help oneself from already maligned situation, everyone tried their best to sail in the direction of wind. IJI was committed, not to allow the government to work peacefully. The opposition parties worked to dislodge the PPP government by not allowing the smooth functioning of the latter while the incumbent government used every opportunity to weaken the former. Lack of patience and lack of political maturity masked the legislature. Moreover, since the clash between PPP government and the Chief Minister Nawaz Sharif raged on. President Ghulam Ishaq Khan was 
always dragging his feet to sign the ordinances and declared that an elected government should pass the laws through legislative procedure (Najdi, 2011).

Nonetheless, Benazir Bhutto government was successful in passing the annual budget for 19891990 from the parliament. As Benazir Bhutto completed her first year in office, the political situation in Pakistan remained unsettled. In the following months, Benazir Bhutto style of politics became the target of opposition's criticism. The incumbent government allies i.e., Muttahida Qaumi Movement (MQM) and Awami National Party (ANP) left the alliance one by one that gave PPP a tough time in the National Assembly. The loss of allies support in the parliament on one hand, if weakened PPP position then on the other, provided an opportunity to the Combined Opposition Parties (COP) to move forward with a no-confidence motion against PPP government (Aziz, 2009). When the move for the parliamentary overthrow against her government fizzled, Benazir Bhutto claimed that if her majority is crushed in the parliament, the anti-democratic forces along with the opposition had an arrangement to imprison her and the main 1000 pioneers of PPP (Chowdhury, 2003). However, Benazir Bhutto endures no-certainty move yet, did not fabricate accord-based condition for all the political powers to work in. In this way, the world of politics of the nation stayed feeble and flimsy in the days to come. She did not put forth noteworthy attempts to enter exchanges with the opponents (Malik, 2008).

The individual clashes with the president about the administration of legislative issues drove Benazir Bhutto's supporters to accept that President Ghulam Ishaq Khan was titled towards the IJI and was not an unbiased figure. The failure of no-confidence move left Benazir Bhutto's power as leader a flawless personality. Nevertheless, it likewise expanded the previously broadening bay between Ghulam Ishaq Khan and Benazir Bhutto. This truly ends up being a conflict of characters that strengthened the on-going battle between the powers representing the authoritative state and those representing the political state. Right now, the militarycontrolled the result and had settled on business as usual i.e., the law-based procedure to proceed. However, the later developments proved to be otherwise. The position of senior minister was given to Begum Nusrat Bhutto, the then PPP Co-chairperson, MNA and mother of Benazir Bhutto. Moreover, taking undue advantage of his wife's position, Asif Zardari resorted to an assertive approach in the decision-making processes. It was affecting Benazir Bhutto's assertion to perform as a sincere public servant. Additionally, charges of debasement, political support and individual enmity against political rivals harmed her political stance. Therefore, the stains of defilement and nepotism got one of the principal charges when President Ishaq Khan excused her government in 1990 (Ziring, 2006).

\subsection{Policy of Confrontation in National Politics during Second Term}

The way Benazir Bhutto began her second term as a head administrator, growing great working relations with political adversaries and different partners introduced the development and more noteworthy eagerness. Because of PML (J) from Punjab, Benazir Bhutto showed more settlement for her alliance with her rivals in the parliament. Although the first year of Benazir Bhutto's second term as prime minister was portrayed with efforts of overcoming the adversity not just by developing good relationship but also reducing the clashes with different partners. In any case, her methodologies could not appear fruitful when these endeavours showed uselessness, and she went against these efforts and needed to take necessary measure due to threatening political situation. In 1994, a grave political threatening vibe between Benazir Bhutto and her primary political enemy, Pakistan Muslim League (N) ruled Pakistani legislative issues. Neither Benazir Bhutto nor the restriction could show any persistence 
towards each other. The political environment of the nation experienced tremendously the rot in political organizations, across the board defilement, ethnic and partisan brutality in this way prompting rebel circumstances in many pieces of the nation (Amin, 1995).

If truth be told, Benazir Bhutto as a pioneer in the restriction in 1993 had reliably followed a solitary point motivation to topple the administration of Nawaz Sharif and had been using all methods for it. As a counter, Nawaz Sharif was representing a lot more grounded resistance to Benazir Bhutto and was progressively anxious for toppling her legislature essentially through distress governmental issues and a thorough battle through media. The grounds on which Benazir Bhutto had been requesting renunciation of Nawaz Sharif, her legislature was enjoyed practically comparable issues, for example, political exploitation and political remuneration. Nawaz Sharif focused on her organization of defilement in fundamental state possessed organizations and denounced Benazir Bhutto's government for de-accelerating the pace of financial development of the nation. The PPP government went beyond and dropped the agreement of a Turkish Firm Bayinder conceded by the Nawaz Sharif government for the development of Peshawar-Islamabad Motorway. PPP government had all privatisation arrangements of the Nawaz Sharif period examined while designating PPP man Naveed Qamar as leader of the Privatisation Commission. PPP government kept on shutting numerous private part power age bargains, the biggest of them was Hub Power Company's agreement of 1200 Mega Watts. This agreement was unusual as deficit of power in Karachi was only $300 \mathrm{MW}$. Moreover, tariff rate given to the company was three-times higher than any other project. Subsequently, WAPDA made desperate attempts to seek some relief but the pressure of international financial institutions and so called sanctity of investment agreement prevented them from securing a reduction in tariff (Akhtar, 2007).

Benazir Bhutto additionally confronted issues with her sibling, Murtaza Bhutto, mostly in Sindh. The arrival of Murtaza Bhutto to Pakistan had made considerable restriction to her legislature in late 1993. His arrival terrified the earlier pioneer and her companion, Asif Ali Zardari. Some displeased PPP supporters accumulated around him which turned into another significant worry for the PM. Nawaz Sharif likewise upheld Murtaza Bhutto and framed a political partnership that worked vivaciously to debilitate Benazir Bhutto's system and started an enemy of defilement development all through the nation. From 1994 to 1995, Nawaz Sharif alongside Murtaza Bhutto began a Train March, a custom set up by Z. A. Bhutto, and headed out from Karachi to Peshawar (Khan, Khan, \& Rehman, 2017). The immense groups, who partook in the walk alongside those accumulated on the stations, went to the talks of their pioneers. The gigantic groups along the course accumulated in a presentation of the battling and unfriendly systems that portrayed both governmental issues and these two political opponents (Wynbrandt, 2009). The force battle inside the Bhutto family was additionally escalated when Nusrat Bhutto said she would not permit certain PPP individuals from Benazir Bhutto government to visit the grave of her late spouse, Z. A. Bhutto on his introduction to the world commemoration on January 5. Notwithstanding, Benazir Bhutto stayed firm that the commemoration would be commended of course (Amin, 1995).

In September 1996, police executed Mir Murtaza Bhutto close to his home in Karachi. This despondent event was a melancholy clarification of the more terrible rebellion circumstance, particularly in Karachi. This was particularly awful news for Benazir Bhutto since she and her sibling as of late had accommodated their political contrasts after numerous long periods of the showdown. Benazir Bhutto later guaranteed that Murtaza Bhutto's homicide was a piece of an arrangement to destabilize her administration and to clear out the Bhutto family. At the starting stages, the analysis had been endured however finally, the PPP government turned to the 
utilisation of state apparatus for managing the restriction. Mian Muhammad Sharif and Mian Shahbaz Sharif, father and sibling of Nawaz Sharif individually were exposed to abuse by state organizations under regular citizen control. Innumerable evidences were brought against the business family of Nawaz Sharif and his aging father was arrested over several cases of tax evasion, default on loan payments, and misuse of state authority (Amin, 1995). Nawaz Sharif reacted by strikes, shut down of business, wheel jams, fight gatherings and blacklist of congregations. The situation just sent rushes of despondency among the individuals, paying little mind to their gathering affiliations (Yusuf, 1999).

Notwithstanding, PPP's thought process behind this demonstration was that they needed the resistance to dissent as viciously as conceivable to interfere with the proper location of the President to the joint meeting of parliament on 14 November (Aziz, 2009). In this manner, the cleavage between leader and president had come to surface quite a while in the past with the capture of Mian Sharif in the appearance to irritate the restriction. Nonetheless, the authority of the principal political associations to be specific Nawaz Sharif and Benazir Bhutto restricted that conspire and consequently, this arrangement has debilitated the phase of its origination. Regardless, continuously 1996, Benazir Bhutto government had estranged the legal executive, the military, the president, the world financial bodies like World Bank and IMF and the Pakistani public-at-large. A showdown between the Benazir government and the resistance groups went ahead and the executive was proclaimed a security hazard to the national security and respectability of Pakistan. This narrow mindedness of the administration and restriction towards one another gave again a chance to the military and the president to begin pondering the moving down of the chosen government.

\subsection{Confrontational Politics at Provincial Level during First Term}

Certainly, the IJI was built up with the endeavours of Nawaz Sharif. Punjab, the biggest region in Pakistan had an IJI driven government with Nawaz Sharif as boss pastor. In any case, authority over the biggest unifying unit by the IJI, a resistance turned into an experiment for PPP's initiative concerning what degree they put stock in political resilience, rule of law and regard for the larger part rule. Found right now, in the hallway of forces was neglecting to show resilience. It was high time for exchange and arrangements yet the authority from the two sides did not give any sign of persistence. They did not understand the earnestness of the circumstances and did not assume a capable job to let the boat of the majority rule system to cruise easily. IJI had an uncomfortable relationship with the PPP government in the middle because of old political competitions. In December 1988, the gathering of Benazir Bhutto and Nawaz Sharif limited the degree of threatening relations for the present, yet conflict existed as the two had high stakes in commanding the legislative issues of Punjab. For PPP, a solid political base right now would have fortified its situation at the inside. Simultaneously, a solid resistance government would have helped draw the limits that have been vague between the focal and the commonplace governments (Rais, 1988).

Besides, the PPP government purposely abused the standards of vote-based system by keeping out restriction boss clergymen i.e., Punjab and Balochistan in issues identified with national significance. Likewise, the two areas had a negligible offer in the usage of the Peoples Work Program (PWP) which was gone through equal apparatus, generally under the locale leaders of the PPP (Arif, 1992). It needed to confront unforgiving restrictions from the IJI. Nonetheless, the military support helped Nawaz Sharif further by increasing a crusade of fierce legislative issues against the PPP government. This circumstance accordingly further debilitated the effectively disturbed majority rule government in Pakistan (Talbot, 2003). Benazir Bhutto's 
government's feeble situation at the middle prompted its reliance on the military as balancing out and affecting power. Therefore, diverting its considerations and energies to make satisfactory strides for the arrangement of pressing issues both at national and provincial levels. Notwithstanding, the central administration of Benazir Bhutto used full force and asserted to show its power in Punjab. The IJI government in Punjab completely opposed and turned out in open confrontation thereby refusing to follow the orders of the central government. This brought about bypassing all the established rights of the federal government (Aziz, 2009). The common government in Punjab even would not stretch out an official convention to the head administrator during her visit to the territory (Ziring, 1990).

In any case, all the negative methodologies of the showdown, reprisal, rivalry, and unpleasantness were adopted in this controversy between the federal and Punjab governments (Kukreja, 2003). Keeping in view these issues of a leader with the IJI government in Punjab, none of these advancements made the undertaking of youthful head administrator simpler. With the help of MQM which had 13 National Assembly seats, PPP shaped government in the Centre just as in the territory of Sindh (Arif, 1994). This plan of collusion with MQM in which PPP had an advantage, remained an incredible obstacle in the fruitful working in the parliament. Additionally, the alliance with the MQM damaged her credibility within the party particularly among the Sindhi nationalists who were among her strongest supporters. Because of political exigency, an understanding was marked in December 1988 between the MQM and PPP (Aziz, 2009). Accordingly, it was vowed to ensure the interests of Sindhis paying little heed to language, religion, or root just as to get rid of viciousness and to help the standard of law. The understanding showed brief as it could not lead the ideal points i.e., to bring harmony and collaboration among the Sindhis and the Muhajirs in Sindh.

The MQM had brought up criticisms about the administration considering the shared framework and PPP was established among the rustic populace in Sindh. As a pioneer of Muhajirs, Altaf Hussain alongside his devotees was not in acceptable terms with the Pashtun people group, Punjabi, and Baloch in Karachi since neighbourhood political force appeared to be evading the Muhajirs (Malik, 2008). Altaf Hussain blamed Benazir Bhutto for manipulating and reprimanded her for neutralizing the understanding. Such conditions rushed mystery dealings between the MQM and Nawaz Sharif, and Benazir Bhutto was a typical objective. With this, another improvement occurred as MQM officially joined the IJI which had developed into a bigger union called the Combined Opposition Parties (COP) resolved to cut down the PPP government. The instance of Khyber Pakhtunkhwa (at that point NWFP) was the same because within the sight of a strong President and Army Chief Mirza Aslam Baig, the government could scarcely take any autonomous choice. Despite rehashed requests of PPP common government's alliance accomplice, the ANP, to satisfy the responsibility, Benazir Bhutto government could not supplant the Governor of Khyber Pakhtunkhwa. He was a retired Brigadier from the Army and was selected by President General Ziaul Haq. Ghulam Ishaq Khan and Mirza Aslam Baig end up being the genuine obstacles for the chosen legislature of Benazir Bhutto to supplant him (Rizvi, 2003).

\subsection{Policy of Regime Change in Provinces during Second Term}

Initially, Benazir Bhutto had encouraged the political participation by accommodating all the stakeholders both at federal and provincial levels. Ghulam Mustafa Jatoi's son was appointed as minister in Sindh government and the son of Balkh Sher Mazari was given a ministerial position in the Punjab government. Similarly, two ministers in the Punjab cabinet were the son of Mustafa Khar as well as Nasrullah Khan (Kamran, 2008). However, the situation at political 
front in provinces was not friendly and Punjab again proved to be the cause of disagreement for PPP. The judgement of the Lahore High Court to restore Manzoor Wattoo's government in Punjab in November 1996 caused considerable embarrassment for the federal government. This was a severe blow as a PPP government of Sardar Arif Nakai was installed by the Prime Minister just a year back in September 1995 (Aziz, 2009). Asif Ali Zardari would not accept this reinstatement and went to Lahore, for the purpose to shift the allegiance of provincial assembly members through horse trading (Hussain, 1996).

In early 1994, though, Benazir Bhutto tried to capture the government of Khyber Pakhtunkhwa by bringing to her side a number of independent members of the government having ministerial position, and more advantages on joining the party union. The goodwill of the opposition and backing of the presidency could have been cashed to secure her position and government. Instead, Benazir Bhutto planned to oust provincial government through constitutional manoeuvring. She had no tolerance for democratically elected coalition government of PML (N) and ANP. She sought to install the government of PPP in the province despite being a minority. Within four months of the election, the PPP leadership in the province led by Aftab Khan Sherpao, manoeuvred to lure away eleven independent members who had initially supported the PML (N) government in the province (Aziz, 2009). He was successful in buying the loyalties of Independent and two PML (N) members of the Provincial Assembly with the help of Mehran Bank money. Thus, PPP acquired a majority in the provincial assembly through paying a huge sum of money in bribes (Ziring, 1997).

Believing she had to neutralize Nawaz Sharif, Benazir Bhutto took advantage of the unstable conditions in the Khyber Pakhtunkhwa (then NWFP) to prorogue the provincial government and impose governor's rule. The federal government asked the President to impose governor's rule in the province under Article 234 of the Constitution to remove the current government which he complied with (Kalia, 2011). With lifting of the restrictions on political activity after the installation of a PPP government following governor's rule of two months provoked the opposition. The opposition, however, could not remain silent in the face of this obvious effort to impose her party's rule throughout the country. Protest meetings were held from Peshawar to Islamabad and all the way to Lahore. The undemocratic action from the outset opened another round of confrontational politics, damaging democratic discourse. The opposition launched Save NWFP Campaign. The opposition boycotted the sessions of the Parliament and challenged the government on virtually every issue. This example reflected on Benazir's disregard for legitimate opposition and on how she did not promote the much-needed culture of tolerance based on respect for majority rule (Mehmood, 1998).

Benazir Bhutto's first government had been overthrown at a time when Pakistan was confronting grave problems particularly law and order. Since regaining authority for the second term, Benazir Bhutto had found herself battling with serious issues with opposition including the Mohajir Quami Movement (MQM) in Karachi. The MQM along with PML (N) had become a strong opposition in the Sindh Assembly. In late April 1994, Mohajir tensions with the government in the province of Sindh increased thus leading to violence in which many died. Many of the clashes were between MQM and PPP workers; some were between Sunni and Shia sects. Those involved in the sectarian violence, and yielded to pressures from religious parties by postponing amendment of the country's "blasphemy" laws, were not prosecuted or punished by the Benazir Bhutto's government, like its predecessors. The climate of insecurity reached the highest point after the two American consulate's officials were killed on March 8, 1995. The Karachi Stock Exchange (KSE) fluctuated considerably \& fell by 29 points mainly due to political turmoil and uncertainty in Karachi. 
Violence had extremely increased and citizens expressed profound frustration with the incapability of Bhutto's administration to end it. Benazir Bhutto government launched a crackdown against MQM. Peace in Karachi remained elusive as MQM activists were not ready to allow PPP in administering duties. The followers of Altaf Hussain trusted neither the two major political parties nor the army. They propagated the intensity of state led violence against fellow Muhajirs by using pamphlets, audio cassettes, and video cassettes. A member of the Muhajirs charged that Muhajirs were victims of discrimination and ethnic cleansing. The violators were the elite Sindhis which included the Bhutto family. He charged that the Sindhis had dominated most of the nation which included only about 2 percent of the population. Many Pakistanis also felt that Benazir's government had done nothing to stop the wave of violence against the Muhajirs Community in Karachi. Altaf Hussain along with his few confidants had been awarded British citizenship, but they continued their involvement in Karachi through a well-organized system of communications (Malik, 2008). The opposition, particularly MQM continued to be at loggerheads with PPP throughout 1993 to 1996.

\section{Conclusion}

The PPP came into under the leadership of Benazir Bhutto after 12 years of military rule. However, the transition to civilian rule proved a bitter experience not only for democratic consolidation but for PPP as well. It was an opportunity for the party to rectify the mistakes committed in the past and get better its image in public and improve its vote bank by playing the game according to the rules. It would have not only set healthy traditions in the national politics, rather positive changes could be brought in its style of politics especially the dealing with opposition at federal and provincial level. Resultantly, PPP lost the opportunity for the second time since its birth in 1967. The practices which PPP resorted to were in sharp contrast to the commitment which its leader had been pronouncing so loudly in public earlier. Nonetheless, the PPP faced considerable impediments from the opposition and thus caused damage to democracy in Pakistan. Benazir Bhutto created troubles for her government by clashing with Nawaz Sharif in Punjab as well as with other provinces and particularly due to lack of consensus building with MQM in Sindh. Apart from this, other political parties of Pakistan were equally responsible for the flimsy state of democracy as they did not play their part for promoting democracy in the country. Similarly, PPP did not prove its worth as it had left no stone unturned in humiliating the opposition especially Nawaz Sharif.

After the 1993 general elections, instead of seeking lessons from the blunders committed one after another, PPP seemed determined to follow the same old pattern of politics disregarding the spirit of the manifesto. One wonders why a party leader, who had her brought up in the West, got education from the prestigious Western academic institutions and fully accustomed to the democracy and its pre-requisites, was failing to introduce it in Pakistan. Benazir Bhutto did everything that General Ziaul Haq had wanted his hand-picked politicians to do. Every step she took disgraced the political process, from bribing elected representatives to secure their support in the National Assembly to letting her husband handle the affairs of the premier's secretariat. Although, initially Nawaz Sharif claimed to offer her party support to the government but later on, all this proved a myth than reality. Nawaz Sharif openly demonstrated defiance to the writ of federal government and resorted to Long and Train Marches. He as Chief Misnister and as opposition leader caused damage to democracy due to his attitude of noncooperation with his political rival Benazir Bhutto to complete the mandated period. Opposition parties also demonstrated no spirit of tolerance and disallowed the smooth functioning of democratic process to flourish. PPP also resorted to undemocratic means including suppression of the opposition both at federal and provincial lelvels. 


\section{References}

Ahmad, N., Bano, A., \& Rehman, A. U. (2017). Impact of the informal institutional forces on the local government elections on Pakistan. Liberal Arts and Social Sciences International Journal (LASSIJ), 1(1), 62-70.

Akhtar, H. N. (2007).If truth be told: An alternate history of Pakistan. Lahore: Sang-e-Meel Publications.

Amin, T. (1995). Pakistan in 1994: The politics of confrontation. Asian Survey, 35(2), 140149.

Arif, K. M. (1992). Pakistan's politics scene, 1984-1992. Lahore: Rohtas Book.

Arif, K. M. (1994, October 10). Faulty political order. Daily Dawn.

Aziz, S. (2009). Between dreams and realities: Some milestones in Pakistan's history. Karachi: Oxford University Press.

Burki, S. J. (2006). Historical dictionary of Pakistan. USA: Scarecrow Press

Chowdhury, M. H. (2003). Democratization in South Asia: Lessons from the American institutions. London: Ashgate Publishing Limited.

Fatton, R. Jr. (1998). The Impairment of democratization: Haiti in comparative Perspective. Comparative Politics (Vol. 2).

Hofmeister, W., \& Karsten, G. (2011). Political parties: Functions and organization in Democratic societies. Singapore: Konrad Adenauer Stiftung.

Hussain, H. (1996).Benazir Bhutto: Fall from Grace. Newsline.

Kalia, R. (2011). Pakistan: From the rhetoric of democracy to the rise of militancy. London: Rutledge.

Kamran, T. (2008). Democracy and governance in Pakistan. Lahore: South Asia Partnership.

Kapoor, A. (1991). Pakistan in crisis. London: Routledge.

Khan, A., Khan, T. M., \& Rehman, A. U. (2017). Government-Opposition relations amidst the provincial autonomy during Bhutto regime. Journal of the Research Society of Pakistan, 54(2), 41-52.

Kukreja, V. (2003). Contemporary Pakistan: Political processes, conflict, and crises. New Delhi: Sage Publications.

Malik, I. H. (2008). The history of Pakistan. London: Green Wood Press.

Mehmood, S. (1998). Democracy in Pakistan: Value change and challenges of institution building. The Pakistan Development Review, 37(4), 281-298.

Mehmood, S. (2003). Pakistan: Political roots and developments. Karachi: Oxford University Press.

Najdi, F. A. (2011). Benazir: A women of peace and reconciliation. Pakistan Pictorial. Islamabad: Pakistan Publications.

Rais, R. B. (1988). From command to conciliation politics. Asian Survey, 29(2), 199-206.

Rizvi, H. A. (2003). Military, state, and society in Pakistan. Lahore: Sang-e-Meel Publications.

Rizvi, H. A. (2009). The military and politics in Pakistan. Lahore: Sang-e-Meel Publications.

Shafqat, S. (1997). Civil-military relations in Pakistan. Oxford: Westview Press.

Sirohey, I. A. (2000). Truth never retires. Lahore: Jang Publishers.

Talbot, I. (2003). Pakistan: A modern history. London: Hurst \& Company.

Wynbrandt, J. (2009). A brief history of Pakistan. New York: Facts on Files.

Yusuf, H. (1999). Pakistan: A study of political developments 1947-97. Sang-e-Meel Publications.

Ziring, L. (1990). Pakistan in 1989: The politics of stalemate. Asian Survey, 30(2), 126-135.

Ziring, L. (2006). Pakistan in the twentieth century: A political history. Karachi: Oxford University Press. 